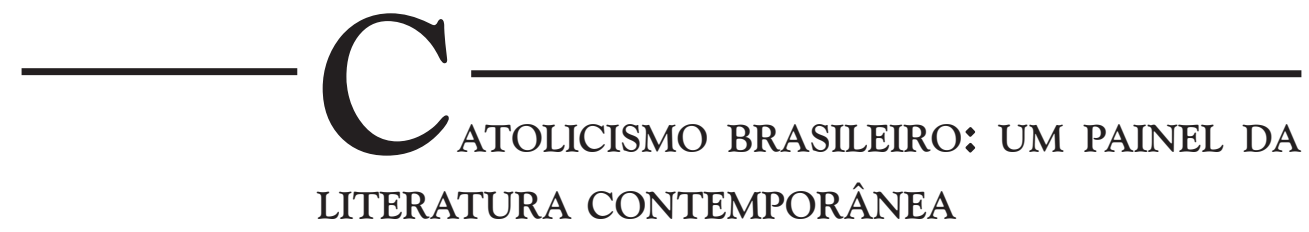

Flávio Munhoz Sofiati Alberto da Silva Moreira

\title{
Introdução
}

É preciso voltar a pensar o catolicismo brasileiro em sua totalidade. Os estudos sobre a instituição católica não saíram de cena, mas as análises tornaramse muito pulverizadas: estuda-se o catolicismo tradicional, popular, carismático, midiático, no entanto, urge um entendimento contemporâneo do fenômeno como um todo. Em levantamento bibliográfico realizado para a pesquisa acerca do tema, identificamos certa defasagem no número de artigos que tratam do assunto - em comparação, por exemplo, com os estudos sobre pentecostalismo -, sendo que a maioria dos artigos aborda algum grupo ou aspecto específico presente no interior da Igreja Católica².

Os interessados em pensar o fenômeno em sua totalidade tendem a assumir a perspectiva, defendida na análise de Antônio Flávio Pierucci, de se fazer a sociologia de um catolicismo em declínio (Camurça 2006). Contudo, nosso interesse aqui é entender em que medida a instituição Igreja Católica em particular e o catolicismo em geral exercem influência no mercado religioso brasileiro. Nossa hipótese inicial é de que ainda há certo constrangimento dos sujeitos na adesão às outras religiões. Consideramos que, apesar da diminuição da importância dessa instituição no cenário religioso nacional, há uma forte presença do catolicismo na cultura da nação, na vida cotidiana do fiel e nas inter-relações sociais estabelecidas no interior da sociedade brasileira.

Assim, pretendemos neste artigo sistematizar e, de certa forma, colaborar com a atualização da bibliografia que estuda os modos e os estilos de ser católico no Brasil 
contemporâneo. Não se trata de uma revisão bibliográfica no sentido estrito, e sim da construção de um argumento a partir da apreciação geral e da discussão com uma bibliografia recente e relevante sobre o tema. A tarefa principal consiste em costurar abordagens fragmentadas do catolicismo e tentar apresentar uma interpretação atualizada, tendo como ponto de confluência a análise dos principais desafios enfrentados pela instituição católica na sociedade brasileira.

Uma das possíveis explicações para a compartimentalização dos estudos sobre o catolicismo é o fato de a própria Igreja Católica, por conta da crise da socialização católica e da individualização das crenças, além do surgimento de novos especialistas midiáticos do sagrado (Moreira 2008), haver perdido muito o controle sobre o processo social de interpretação de seus próprios códigos fundantes. Os variados agrupamentos internos ao catolicismo (bem com os externos a ele) apropriam-se do capital simbólico da instituição e o desenvolvem ou aplicam conforme interesses específicos. As adesões são buscadas sem que os discursos obedeçam a uma forma única de organização ou controle, tornando de fato a atuação católica cada vez mais fragmentada no cenário contemporâneo (Benedetti 2009).

Ao pensarmos a situação interna da Igreja Católica em meio ao contexto apresentado acima, encontra-se uma questão que está muito presente no debate contemporâneo: diante do fim do monopólio católico e do advento de um mercado de bens de salvação cada vez mais plural, estaríamos vivenciando o fim da hegemonia católica? Em artigo publicado recentemente no jornal norte-americano The Washington Post, Sarah Bailey (2017) projeta que os católicos no Brasil se tornarão até 2030 uma religião minoritária. No entanto, entendemos que não existe uma resposta pronta para essa pergunta, sendo preciso considerar que, por um lado, a Igreja Católica no Brasil é uma instituição com uma capacidade impressionante de controlar suas dissidências e de negociar visões opostas dentro de si mesma. Por outro lado, é preciso reconhecer que ela se encontra numa situação cada vez mais crítica para manter a fidelidade de seus membros, diante da crescente liberdade dos indivíduos em relação às instituições religiosas (Benedetti 2009).

O catolicismo na contemporaneidade procura sobreviver num cenário marcado por uma cada vez "[...] menor regulação institucional sobre as práticas e os valores adotados" (Martins 2009:127). Como o impacto da secularização tem sido muito forte sobre essa instituição, é necessário compreender como ela tem administrado seus recursos nessa nova conjuntura. Visando colaborar com os debates em curso, o artigo está organizado da seguinte maneira: inicia-se com a discussão acerca dos dados estatísticos sobre os católicos; em seguida, problematiza-se os principais elementos da visão sociológica focada no tema do "declínio católico"; depois, analisase a diversidade interna do catolicismo brasileiro, mostrando como tal diversificação contribui para a manutenção ou, em alguns casos, para o fortalecimento do catolicismo na atualidade; e, por fim, ensaia-se algumas interpretações mais abrangentes acerca do catolicismo no Brasil contemporâneo. 


\section{Sobre os números}

Os cristãos, nas suas diversas orientações, ainda constituem o bloco religioso mais numeroso no mundo, somando 31\% da população mundial em 2015 segundo o Pew Research Center (PEW 2017). No entanto, no velho continente, berço do catolicismo, não é mais a religião hegemônica, visto que quase 75\% dos cristãos estão fora da Europa. Em contrapartida, há uma presença significativa na América Latina. A Igreja Católica ainda tem no mundo cerca de 1,1 bilhão de adeptos (Teixeira 2009a), número que a coloca, em termos absolutos de fiéis vinculados à mesma instituição e ao mesmo ramo religioso, como a instituição religiosa mais importante da humanidade. Os países mais católicos do mundo são: Brasil, México, Estados Unidos, Filipinas e Itália (Rodrigues 2013). Com relação à América Latina, o Brasil surge na visão de José Casanova (Isto É 13/03/2012) como uma potência religiosa, um centro mundial de catolicismo e de protestantismo global. Mas, apesar da hegemonia cristã no mundo, ao analisarmos os dados específicos sobre o catolicismo, evidencia-se que sua matriz romana se encontra em situação de desgaste diante da pluralidade de ofertas de bens de salvação no campo religioso global. Conforme retrata Camurça (2011:2), a Igreja Católica na contemporaneidade tem sofrido os efeitos da secularização e da laicização. Essa instituição tem experimentado "um declínio no seu antigo monopólio de influência na sociedade".

Certamente, são inegáveis o papel e a influência da Igreja Católica na formação da sociedade brasileira. Sua posição privilegiada durante a maior parte da história do país veio, evidentemente, do regime do Padroado Régio, quando o catolicismo era a religião oficial do Estado. A hegemonia do catolicismo nos primeiros 350 anos de colonização, mais do que a própria instituição católica oficial, influenciou profundamente a cultura brasileira, com a inserção de seus valores religiosos e morais, posturas e visão de mundo, além de influir na constituição dos grupos sociais que dão sentido ao nosso modelo de nação (Azzi 2008). Desnecessário dizer que esse catolicismo, por mais que não negasse o discurso oficial da instituição, sempre foi sincrético, realizando bricolagens, hibridações, adaptações, concessões e negociações de toda ordem com as culturas e religiões africanas e indígenas, além do espiritismo, das religiões dos migrantes e, mais tarde, com os movimentos religiosos da Nova Era.

Uma visão sócio-histórica que ultrapasse a leitura superficial dos dados estatísticos evidencia que o catolicismo deixou de ser a "religião dos brasileiros", apesar de ser ainda a "religião da maioria dos brasileiros" (Teixeira 2013). O Censo de 2010 apontou que, além da diminuição relativa na proporção de fiéis, houve pela primeira vez a diminuição absoluta no número de católicos: estes passaram de 125 milhões para 123 milhões de adeptos, caindo de 73,6\% para 64,6\% da população. Pesquisas parciais parecem indicar que, em outubro de 2016, a proporção de católicos já estaria abaixo dos 55\% da população (Datafolha 2016).

Konings \& Mori (2012:1209-1212) resumem os dados básicos do Censo de 2010 sobre o catolicismo no Brasil da seguinte maneira: a) existe um fim do mo- 
nopólio católico; b) há uma forte presença do catolicismo nas regiões Nordeste e Sul; c) há uma presença enfraquecida nas regiões de fronteira e de forte migração; d) o catolicismo manteve sua força no campo em detrimento da cidade; e) há uma composição equânime no quesito gênero; f) houve um envelhecimento dos fiéis. Os autores elencam quais seriam os principais motivos da forte diminuição dos católicos: a) dado geográfico: houve uma passagem do rural para o urbano, sendo que a Igreja Católica "[...] era fortemente rural, e a tendência a ter comunidades religiosamente homogêneas é mais forte na vida rural, de estrutura patriarcal e forte controle social, que na moderna vida urbana"; b) dado econômico: "Problemas financeiros e/ou de saúde podem levar as pessoas aos cultos neopentecostais, sobretudo aqueles que acentuam os milagres, promessas, descarregos etc"; c) dado religioso: o catolicismo brasileiro "[...] está habituado ao sincretismo, acolhendo em si muitos elementos de tipo mágico. A maior sobriedade do catolicismo pós-Vaticano II afastou até certo ponto esses elementos"; d) dado social: o advento de uma modernidade na qual "[...] mais que 'grandes relatos', cada um busca construir o próprio relato, o que não deixa de ser expressão de uma hermenêutica na qual cada um possui sua verdade e a constrói” (Konings \& Mori 2012:1219).

Os autores enfatizam ainda que a queda histórica dos católicos nos dados do Censo significa acima de tudo a passagem de um "[...] regime de religiosidade "herdada' ou 'ambiental' para o cristianismo de opção ou de convicção" (Konings \& Mori 2012:1216). Além disso, afirmam que as pessoas não se sentem mais obrigadas a pertencerem a uma organização religiosa.

Diante das inúmeras possibilidades de análise dos dados censitários, deve-se levar em consideração que a Igreja Católica com 123 milhões de fiéis continua sendo a maior e mais importante instituição religiosa do Brasil. A segunda igreja mais numerosa no país é a Assembleia de Deus com cerca de 12 milhões de adeptos, apenas 10\% do número de católicos, além de estar dividida em dezenas de denominações diferentes.

Nossa sociedade, em sua composição cultural, é profundamente influenciada pela lógica cristã impressa pelo catolicismo popular, que soube aproveitar as trocas com as religiões de matriz africana e indígena, destacando-se no contexto histórico de construção da nação. Todavia, não é mais possível identificar automaticamente o "ser" católico com o "ser" brasileiro. Já nos anos 1990, Pierre Sanchis (1994) destacava que a Igreja Católica não tinha mais a hegemonia da verdade no campo religioso brasileiro.

Ao pensarmos o caso do catolicismo no Brasil, esse novo contexto pode ser interpretado em relação à emergência do indivíduo e à crescente desinstitucionalização da experiência religiosa (Teixeira 2013); isto é, ocorre um processo de fragilização da tradição e fortalecimento da busca de alternativas individuais de salvação (Almeida \& Barbosa 2013). A consequência seria um cenário religioso marcado pela "mutação sociocultural", com a multiplicação das opções religiosas existentes, o enfraquecimento na intensidade da adesão religiosa, o processo de "desinstitucionalização" das religiões e o "esvaziamento das instituições religiosas tradicionais" (Teixeira \& Menezes 2006:8). 
Autores como Faustino Teixeira (2009a) colaboram para se pensar as mudanças no mercado de bens de salvação numa perspectiva de diversificação das experiências religiosas. Pierre Sanchis (2013) demonstrou que a mudança civilizacional vivenciada na contemporaneidade exige uma leitura apurada dessa diversificação nas realidades concretas. $\mathrm{O}$ autor insiste em três pontos: a) é preciso lembrar que não há religião sem crentes, ou sem indivíduos religiosos; b) que o cenário atual aponta para um processo de desinstitucionalização crescente; c) que a circulação intensa (trânsito religioso) e a eventual múltipla pertença se tornaram legítimas. Da mesma forma, os últimos estudos de Lísias Negrão (2009) apontam para um cenário de múltiplo pertencimento religioso, confirmando a avaliação apresentada acima.

Configura-se, portanto, o cenário descrito por Faustino Teixeira e Renata Menezes (2013:21): "A tendência em curso indica a afirmação 'de uma visão cada vez mais pessoal da religião', dispondo os sujeitos de 'dispositivos de sentido' singulares, seja pontuados pelo sincretismo ou pela bricolagem”. Tal contexto produz uma tensão entre a religião universal de conversão individual (o pentecostalismo) e a instituição social que representa a família, as origens, o berço da religião e da tradição (no caso brasileiro, a Igreja Católica). A religião congregacional rompe com todos os laços familiares; é religião desfazendo laços de família, como afirma Pierucci (2006a:31). O autor, em diálogo com Max Weber, sustenta que a "religiosidade soteriológica congregacional como criadora de uma "comunidade social nova" configura uma vida comunitária nova. Os laços sanguíneos que constituem a família são substituídos pelos laços religiosos, estabelecendo uma nova família formada pelos irmãos de fé.

Nas sociedades hodiernas, decaem as filiações tradicionais (Pierucci 2013); ocorre o desencaixe dos indivíduos de seus antigos laços (Giddens 1991), em um processo de "desfiliação" que leva à priorização de vínculos quase só experimentais. Pierucci (2013:50) considera que o declínio indisfarçável do número de católicos "[...] é o traço mais forte e terminante a marcar o panorama atual do campo religioso brasileiro". Ele considera a esfera religiosa brasileira como pós-tradicional e, por isso, vivaz e dinâmica, o que causa o aceleramento do declínio demográfico progressivo da religião da tradição. Trata-se de um "[...] regime concorrencial cada vez mais desregulado pelo Estado e fora do controle da religião dominante" (Pierucci 2013:51). Pierucci (2013:54-55, grifos do autor) afirma que há um "mercado religioso desmonopolizado" que favorece as "conversões individuais, em detrimento das identidades coletivas herdadas".

Diante das leituras apresentadas acima, avaliamos que, mesmo com o aumento da concorrência no mercado de bens de salvação, o catolicismo se apresenta com força na disputa pela preferência dos fiéis. Nesse sentido, é preciso aprofundarmos o debate, discutindo até que ponto o declínio da instituição corresponde à diminuição da influência da cultura católica na sociedade brasileira e no campo religioso. 


\section{Uma interpretação do declínio católico}

Apesar da redução do número de católicos no Brasil, estudos sobre o trânsito religioso demonstram que o catolicismo é ainda a religião de criação da maioria dos brasileiros (Rumstain \& Almeida 2009). A análise demográfica do trânsito religioso no país mostra que é na faixa etária das pessoas de 20 a 65 anos que se encontra a população com percentual inferior de católicos em comparação à média nacional. Mas evidencia-se também um possível "trânsito de retorno", visto que a população idosa é mais católica do que a média nacional (Almeida \& Barbosa 2013).

Em consequência, na análise do processo de "desregulação institucional" (Hervieu-Léger 1999) do campo religioso brasileiro e do aumento do trânsito entre religiões, identifica-se um duplo processo: por um lado, há a desvinculação do fiel em relação à sua instituição religiosa (de origem) e, por outro, uma multiplicação de alternativas religiosas (Rumstain \& Almeida 2009). São as consequências da modernidade, advoga Marcelo Camurça (2013) em alusão à obra de Anthony Giddens. A crise católica seria, portanto, consequência das mudanças religiosas, sociais, culturais, morais, estéticas, científicas advindas da própria sociedade contemporânea. Ao tratar do caso brasileiro, Camurça nos aponta ainda um aspecto específico dessas mudanças:

Uma das explicações mais de fundo para o decréscimo católico é a sua grande dificuldade para acompanhar as migrações internas que revolvem o Brasil contemporâneo. Onde os católicos mais diminuíram e os pentecostais e sem religião mais cresceram, são as regiões das periferias metropolitanas e as fronteiras de ocupação sem presença institucional católica. A estrutura eclesial católica centralizada e burocrática, centrada nas paróquias, não consegue acompanhar a mobilidade dos deslocamentos populacionais como as ágeis redes evangélicas (Camurça 2013:72).

Paulo Gracino Junior (2012) confirma essa tese ao apontar que, nas regiões norte do Rio Grande do Sul, sul de Santa Catarina, interior do Nordeste e interior de Minas Gerais, o catolicismo continua dominante. A porcentagem nessas regiões em 2010 variava de $78,4 \%$ a $86,1 \%$ de católicos, sendo que a média nacional na mesma época era de 64,6\%. Em contrapartida, os estados de ocupação recente, como Amapá, Pará e Acre, com 20\% de pentecostais, superavam significativamente a média brasileira para essa população, que era de $13 \%$.

Concomitantemente a esses números, Silvia Fernandes (2013) demonstra, em sua análise do tema, que a população católica cresce em ritmo sempre inferior à taxa de crescimento populacional, enquanto que os evangélicos crescem acima dessa taxa. A autora defende que é preciso considerar o contexto da interespacialidade e da mobilidade humana para se entender a situação atual da Igreja Católica no Brasil: 
"Sugiro que as experiências de mobilidade humana devem nos instigar à compreensão de seus efeitos na pessoa, na cultura e em vários lugares de sentido da vida, juntamente com a tradição e o enfraquecimento dos discursos de autoridade" (Fernandes 2013:123). Fernandes afirma que a mobilidade deve ser considerada como um dos fatores que levam ao processo de individualização. Entretanto, a própria individualização não explica o cenário religioso contemporâneo, mas ela mesma é consequência de outros processos inerentes à realidade social, oriundos da vida cotidiana.

Nós concordamos com as interpretações apresentadas acima, todavia entendemos que há outros fatores que precisam ser considerados para explicar tanto o papel que a instituição católica ainda desempenha, como a permanência da cultura católica na contemporaneidade. Fazemos esta diferenciação em alusão ao trabalho de Wellington Teodoro da Silva (2018) que insiste na importância de distinguir entre Igreja Católica (clero católico) e catolicismo (leigos). O catolicismo, para o autor, seria composto pelo laicato católico e por seus movimentos e organizações sociorreligiosas. Nossa hipótese é de que a força do catolicismo reside em sua capacidade de se manter permeável à cultura brasileira. Portanto, mesmo que a instituição (Igreja Católica) tenha perdido fiéis, a cultura católica tem se mantido com força no cenário religioso nacional. Vamos esclarecer melhor essa afirmação básica nos parágrafos seguintes.

Entendemos que é necessário considerar que, no caso brasileiro, apesar da diminuição da capacidade da Igreja Católica de regular o mercado religioso, ainda é muito presente o peso dos custos sociais no processo de adesão às outras religiões. Além disso, o trânsito entre denominações e a atual multiplicidade de pertença religiosa (Negrão 2009) parecem indicar uma continuidade com o padrão do catolicismo brasileiro e com sua típica duplicidade histórica de adesões, como católicos/ afro-brasileiros, católicos/espíritas, católicos/umbandistas, católicos/religiões Nova Era. Parece fazer parte do "ethos religioso" brasileiro (fortemente influenciado na sua formação histórica pelo pertencimento de caráter formal ao catolicismo) a duplicidade de adesões, o que faz pensar que essa cultura continua ainda muito presente no contexto contemporâneo. É preciso considerar também que a queda no número de católicos não trouxe necessariamente uma diminuição na presença pública do catolicismo em nossa sociedade. Tomemos, por exemplo, as romarias aos grandes santuários e as grandes festas populares católicas do país (Aparecida ${ }^{3}$, Círio de Nazaré, Juazeiro do Norte, Trindade, Nova Trento, Bom Jesus da Lapa, São Francisco do Canindé, Muquém). Se o número de católicos caiu significativamente e a frequência a missas diminuiu, os santuários católicos não perderam fiéis. Ao contrário, parecem aumentar sua força de atração a cada ano, provavelmente se fusionando e se tornando permeável ao novo perfil de romeiro, o peregrino light, o turista religioso, e mantendo, por sua conexão com o passado, um certo potencial identitário para a "cultura católica" de boa parte da população brasileira.

Ademais, faz-se necessário considerar que os 22,2\% de evangélicos (Censo de 2010) estão reunidos em várias denominações e instituições, apresentando uma 
surpreendente multiplicação e diferenciação interna, sobretudo entre os pentecostais (Machado 2014). Boa parte do que se pode falar sobre diversidade religiosa no Brasil tem a ver não tanto com a entrada de religiões totalmente novas no cenário nacional, mas com um processo de fragmentação institucional e diferenciação interna do pentecostalismo (Moreira 2018).

Estes são os números referentes aos grupos evangélicos no país. Todavia, existe ainda o que podemos chamar de um cristianismo/catolicismo presente ou sincretizado em outras denominações religiosas, como nos espíritas $(2 \%$,$) , nas religiões de$ matriz africana $(0,3 \%)$, nos sem religião $(8 \%)$, e mesmo na categoria genérica das "outras religiões" (3\%). Ao considerar que o espiritismo brasileiro é profundamente cristão/católico (Aubrée \& Laplantine 1990), que as religiões de matriz africana fizeram trocas duradouras com o catolicismo (Bastide 2001), que os sem religião também são, em sua grande maioria, influenciados culturalmente pelo catolicismo (Ribeiro 2009) e boa parcela das outras religiões, para se inserirem no contexto brasileiro, fizeram trocas com a nossa cultura, como no caso da Seicho-No-Ie, em referência às novas religiões orientais (Silveira 2012), é lícito afirmar, então, que a presença e influência do catolicismo no Brasil vai muito além do espaço nominalmente ocupado pela Igreja Católica no campo religioso (Sofiati 2015).

Para alguns autores (Almeida \& Barbosa 2013), vivemos em uma realidade social na qual a matriz cristã/católica continua hegemônica, embora diversificada. Esse é o perfil da diversidade religiosa nacional, debatido nas últimas décadas pelos cientistas sociais da religião (Pierucci 2006b; Camurça 2006). Vivencia-se um cristianismo diversificado, havendo uma multiplicidade e maior diversidade de grupos e denominações cristãs. Entendemos que isso reforça nossa hipótese da manutenção da força do catolicismo no mercado concorrencial, considerando que as novas adesões não seriam totalmente diferentes, ou melhor, não romperiam com a matriz presente na religião tradicional.

Mesmo levando em conta e concordando em parte com o argumento de Campos \& Gusmão (2013:68), que, ao tratar do processo de conversão à Igreja Universal do Reino de Deus (IURD), afirmam a necessidade de se considerar "uma identidade religiosa [iurdiana] que se define por contrastes e aproximações com outras denominações evangélicas e por oposição ao catolicismo e às religiões afro-brasileiras", entendemos que a convivência de mais de um século com o catolicismo não deixou o pentecostalismo clássico e tampouco a IURD simplesmente imutáveis ou imunes às suas influências. Pensar o contrário parece ir contra a razão sociológica e os dados colhidos pela observação de campo de diversas pesquisas acerca do tema (Costa 2011). Não afirmamos que o pentecostalismo é ou foi homogêneo, nem que assumiu ou foi digerido pelo que Bittencourt Filho (2003) chamou de a "matriz religiosa brasileira". No entanto, parece razoável pensar que, ao longo desses cem anos, o pentecostalismo, para além do seu anticatolicismo (que, de um ponto de vista identitário, é extremamente produtivo e funcional), realizou diversos empréstimos, negociações e hibridações com a cultura religiosa brasileira (para não usar o termo "catolicismo popular"). 
Esse processo tem sido observado justamente em relação àquele pentecostalismo que alguns pesquisadores consideram "puro" (existe uma religião "pura"?), o da Assembleia de Deus. Algumas das mudanças ou transformações em curso na igreja Assembleia de Deus - que, de resto, não é uma entidade, mas uma quase-marca sob a qual se abrigam centenas de igrejas e ministérios distintos - se devem provavelmente às influências recebidas, entre outras, da Igreja Universal (a chamada onda de "neopentecostalização"). O fato é que tais transformações estão tornando o pentecostalismo cada vez mais "brasileiro" e mais enraizado no cotidiano da cultura brasileira. Vejamos algumas mudanças observadas justamente numa Assembleia de Deus tradicional no interior do Brasil ${ }^{4}$ : abandono progressivo de posições radicais e do sectarismo religioso; adoção da teologia da prosperidade nas pregações, sorteando carros e motos nos cultos; adoção de ritos e símbolos, como o uso de água, pedras, óleo, rosas, objetos abençoados, corredor dos milagres e outros; promoção de shows gospel para arrecadar fundos, manter e atrair os jovens; abandono dos tradicionais usos e costumes de santidade pentecostal, especialmente os dirigidos às mulheres; redução significativa da pregação milenarista e das crenças escatológicas (retorno iminente de Cristo, julgamento final, inferno e salvação celestial) (Costa 2011).

Além dessas, os pesquisadores têm observado outras mudanças nas igrejas pentecostais (tanto clássicas como "neopentecostais") que surpreendem por sua proximidade ao catolicismo vivido no Brasil até pouco tempo pela maioria da população: a adoção e ressignificação da prática dos esportes, o pragmatismo nas trocas simbólicas, a incorporação das festas juninas católicas, a desdemonização e adoção progressiva do carnaval e de festas funk, e a incorporação de espetáculos no culto. Um recente survey entre jovens pentecostais mostra que mesmo um dos traços mais típicos que distinguem evangélicos de católicos na esfera pública - o consumo de bebidas alcóolicas - está sendo flexibilizado5.

Dessa forma, pensamos que uma abordagem teórica como a de Campos \& Gusmão (2013), que ressalta as rupturas, as singularidades, as fronteiras e aquilo que caracteriza o próprio das igrejas pentecostais, é muito oportuna, mas não se deve fechar diante dos fortes indícios empíricos que apontam também para a existência de empréstimos e hibridações do pentecostalismo com o catolicismo difundido na cultura brasileira. Os depoimentos de fiéis e de pastores colhidos por Campos \& Gusmão (2013) em sua investigação registram a visão e o sentido que os atores religiosos dão à sua ação em determinado contexto historicamente situado. Mas o horizonte de tempo da formação da cultura (e mesmo das instituições religiosas) revela estratégias, oposições, mudanças e negociações que ultrapassam o discurso temporalmente localizado dos indivíduos, sobretudo se assumimos uma perspectiva histórica de longa duração. Para Hervieu-Léger (1999), é preciso pensar a continuidade por dentro da descontinuidade, pensar a permanência por meio da assimilação mutante do outro. Neste processo constante de negociações e apropriações, propostas religiosas rígida e formalmente anticatólicas, como o pentecostalismo, podem muito bem assumir ou 
atualizar formas do catolicismo. Por isso, insistimos que uma sociologia do catolicismo brasileiro não pode se restringir a uma sociologia da Igreja Católica (ou excluir instituições religiosas formalmente concorrentes).

Nos estudos sobre o catolicismo, uma abordagem inovadora a ser considerada é a concepção concêntrica proposta por Reesink (2013). Tal modelo concêntrico do catolicismo, que mira o objeto a partir de uma perspectiva do alto ou de fora, ajuda a considerar o campo católico como um todo, e essa é justamente nossa tentativa neste artigo: articular uma visão dialético-compreensiva, abrangente, de um fenômeno multifacetado como o catolicismo brasileiro.

O forte da concepção concêntrica do catolicismo elaborada por Reesink, entre outras vantagens, é o fato de que ela, ao favorecer a permeabilidade e a combinação entre orientações e posições muito diversas dentro do mesmo campo católico, coloca weberianamente o peso na iniciativa e no sentido dado pelos indivíduos à sua ação e à sua escolha religiosa. De fato, nenhum nativo nomeia a si mesmo "católico popular". Além disso, a identificação do "catolicismo popular" com um pertencimento às classes economicamente pobres, ainda que tenha elementos a serem considerados, é ilusória e não ajuda a entender como ricos e abastados podem ser, eles mesmos, agentes importantes na difusão do "catolicismo popular". Por outro lado, a ênfase (mais do modelo gráfico do que da concepção teórica) na localização "topográfica" dos indivíduos não favorece a visibilidade da ação concertada de grupos ou coletivos dentro do campo católico. A metáfora ou imagem do modelo concêntrico também não consegue caracterizar de modo suficientemente satisfatório em que consiste o "centro teológico" do catolicismo e o que, ou quem, assegura sua relativa estabilidade. É notável que qualquer localização, demarcação ou movimento dos agentes dentro do círculo dependa de sua posição relativa ao centro teológico estável, inclusive a delimitação das margens. Mas centro teológico sempre evoca centro legitimado de controle, o que reforça a concepção bourdieusiana de um clero legitimado ou hegemônico. Apesar da estrutura nuclear, fundamental para o modelo concêntrico, ele não torna muito visível a tensão ou o conflito existente entre os diversos agentes ou grupos dentro do catolicismo (como a noção bourdieusiana de campo). Os conflitos e relações de poder parecem ficar ensombreados pelas possibilidades múltiplas de combinação, permeabilidade e de deslocamento dos fiéis ${ }^{6}$. Parece-nos que, nesse sentido, o modelo concêntrico precisaria incluir os grupos ou movimentos no catolicismo brasileiro que têm seus próprios centros (ou núcleos) teológicos, muitas vezes em diametral oposição ao centro teológico "central" ou ao núcleo teológico de outros agrupamentos.

Há outro fator complicador para qualquer concepção topográfica ou de superfície bidimensional ${ }^{7}$ : a fonte de tensão ou conflito entre os centros (ou núcleos) teológicos de cada agrupamento nem sempre é de natureza "teológica", mas muitas vezes de ordem política. Há diferentes opções políticas que precisam ser teologicamente justificadas. Tomemos o exemplo do chamado Cristianismo da libertação - por Michael Löwy (2000) - em relação ao Cristianismo conservador. Há uma quantidade 
substantiva de agentes religiosos (clérigos e leigos) envolvida nas pastorais sociais da Igreja Católica: Comissão Pastoral da Terra, Conselho Indigenista Missionário, Pastoral do Migrante, da Juventude, dos Povos da Rua, Pastoral Carcerária, Curso de Verão, Centro Ecumênico de Estudos Bíblicos, Encontros Intereclesiais das Comunidades de Base, etc. Todos esses grupos e iniciativas, com suas práticas discursivas, simbólicas, litúrgicas e políticas estão frequentemente em conflito aberto ou camuflado com práticas discursivas, simbólicas, litúrgicas e políticas de grupos ligados ao Opus Dei, aos Legionários de Cristo, aos seguidores de Olavo de Carvalho, padre Paulo Ricardo, bispo Marcel Lefebvre e, em boa medida, à Canção Nova ou a grupos carismáticos mais à direita. Ambas as correntes possuem núcleos teológicos próprios, instituições duradouras e formadoras de habitus, visões de mundo relativamente estáveis e diferentes entre si. A consanguinidade religiosa de berço não parece aproximá-los nem diante, digamos, de um "inimigo comum". Pelo contrário, não se tem notícia de que bispos como Pedro Casaldáliga se tivessem unido a Olavo de Carvalho ou ao Monsenhor Jonas Abib no esforço por combater a concorrência pentecostal e trazer fiéis de volta.

Outro exemplo de que no catolicismo brasileiro não se pode facilmente localizar um centro teológico, pelo menos não um centro hegemônico, é a atual estratégia de oposição, mais discreta que escancarada, às medidas e ao pensamento do Papa Francisco (que deveria representar o "centro" por excelência). Uma parte significativa dos bispos católicos reafirma oficialmente a unidade e a obediência ao Papa, mas, na prática, seus pronunciamentos são silenciados, seus documentos engavetados e as práticas religiosas e políticas conservadoras são mantidas (Sofiati \& Morais 2016, 2017). O fenômeno em si não é novo, pois, no passado, os setores progressistas fizeram algo parecido com os papas conservadores.

De todo modo, pensamos que um modelo concêntrico do catolicismo não afeta nossa tese principal da supervivência do catolicismo no cotidiano da sociedade brasileira, apesar da diminuição numérica dos católicos ou do relativo enfraquecimento da instituição Igreja Católica.

Identificamos dois fatores que podem confluir para manter a força do catolicismo no cenário brasileiro e, talvez, com um grau mais alto de incerteza, manter a Igreja Católica senão numa posição hegemônica, certamente numa posição privilegiada. Por um lado, identificamos o próprio contexto cultural-religioso do país que, como vimos, mostra sua vocação para as trocas, bricolagens, trânsitos e negociações simbólicas, e por isso mantém vivas estruturas profundas do catolicismo enquanto "cultura popular". Por outro, evidenciamos a crescente fragmentação e diferenciação do pentecostalismo brasileiro, as fortes disputas internas no subcampo pentecostal - não por último por interesses divergentes na política e na mídia. Tal diversificação interna, se multiplica o número de seguidores e de instituições, dificulta crescentemente a questão da representatividade e da identidade comum num campo religioso em constante disputa. Em termos de visibilidade social, a Igreja Católica parece manter uma imagem de maior coesão, independência e solidez institucional. Por enquanto, 
é importante considerar pelo menos que esses elementos não devem ser descartados de antemão em nome de uma sociologia do declínio católico. Entendemos que há necessidade de se produzir uma sociologia da nova configuração católica que seja capaz de apreender todos os aspectos dessa presença multifacetada na sociedade brasileira.

Diante do exposto, quais são os aspectos fundamentais do vínculo católico no Brasil contemporâneo? Algumas considerações ajudam a responder a essa questão, sendo que um ponto possível de partida para se pensar o tema é a constatação feita por Pierucci quando afirma que: "O 'barato' de ser católico é fazer parte de uma religião que não precisa ser seguida à risca pela maioria dos fiéis. Reside nisso parte da força do catolicismo, mas grande parte, também, de sua fraqueza" (2009:15). Acompanhando essa consideração, segue-se a observação de Teixeira (2009a:19): "No caso do catolicismo, constata-se que o número de praticantes, ao contrário da tradição protestante, é reduzido, se comparada com a grande massa dos católicos, que mantêm 'frouxos vínculos nominais' com sua tradição religiosa”. Tal cenário de precariedade dos vínculos possibilita que o fiel católico, conforme Carlos Rodrigues Brandão (2013), exerça sua vinculação de forma plural. Isso ocorre tanto em relação às sensibilidades do modo de ser católico, como na relação, de aproximação e distanciamento, com a própria instituição religiosa.

Alguns autores, como Teixeira \& Menezes (2009), acreditam ter identificado um processo de reaquecimento, reavivamento e readesão ao catolicismo: "O catolicismo não é somente uma 'identidade constituída', o 'estrutural institucionalizante', mas é também o instituinte, que revela um dinamismo de reinvenção permanente e um impulso renovador" (Teixeira \& Menezes 2009:9). Os autores advogam o potencial de um catolicismo desde sempre plural no Brasil de incorporar a diversidade, de adaptar-se às novas situações, de se abrir e se permitir diversificar. Brandão (2004) entende que há no catolicismo quase todos os estilos de crenças e práticas existentes fora dele. Mas como entender essa pluralidade, esse sincretismo católico, essa bricolagem e as maneiras de se compreender o católico no Brasil? Seria essa a consequência de se colocar como religião aberta em um campo religioso em plena disputa de fiéis? Como podemos pensar, explicar a diversidade católica? Pode-se falar em culturas católicas (Mariz \& Theije 2008), em estilos culturais de ser católico (Teixeira 2009a), ou precisamos mudar nossa compreensão do catolicismo segundo a lógica contemporânea de se pensar a cultura como prática social (Steil 2009)? São questões que exigem uma interpretação coerente da diversidade católica no país e nos impõem a necessidade de pensar os diversos catolicismos em seu conjunto, ou seja, a partir dos elementos que os identificam com algum grau de referência à instituição católica.

\section{A força na diversidade - as tipologias do catolicismo brasileiro}

Acerca do tema da diversidade interna do catolicismo, diferentes autores aventuraram-se em formular modelos interpretativos que, em geral, não estabelecem 
a distinção, proposta neste texto, entre a instituição católica e o catolicismo. Identificamos uma proposta de diferenciação, mesmo que em formato incipiente, em Camurça (2013), que, buscando caminhos para desenvolver uma etnografia do catolicismo brasileiro, divide os fiéis entre carismáticos, paroquianos, membros das CEBs e das novas comunidades. Em sua análise, entendemos que a instituição é mais presente entre os "paroquianos" e mais distante dos outros segmentos apresentados.

João Batista Libânio (1999), por sua vez, usando a noção de "cenários da igreja" e focado na instituição, divide a Igreja Católica em quatro grupos: Igreja da instituição, Igreja da pregação, Igreja da práxis libertadora e Igreja carismática. Em um de seus últimos livros Libânio (2012), sempre vivaz em suas observações acerca do catolicismo, menciona um quinto cenário: a Igreja plural, fragmentada, pós-moderna, configurada numa simbiose dos quatro cenários anteriores. Trata-se de uma análise intraeclesial, isto é, do ponto de vista de um teólogo que vive a dinâmica interna da instituição. Deste mesmo ponto de vista, Leonardo Boff (1994) também ofereceu "modelos" para se pensar a Igreja Católica: Igreja como totalidade, Igreja moderna, Igreja a partir dos pobres e Igreja mãe e mestra.

Considerando as abordagens extraeclesiais, externas ao pertencimento católico e a partir das ciências sociais, temos, por exemplo, a interpretação de Löwy (2000), que pensa a diversidade interna do catolicismo recorrendo ao conceito gramsciano de tendências orgânicas. Löwy identifica na Igreja Católica atual quatro dessas tendências: uma igreja tradicional, uma igreja reformista, uma igreja radical e uma igreja modernizadora conservadora. Interpretamos que a abordagem desse autor considera a interconexão entre o aspecto institucional e as práticas mais autônomas dos leigos na sociedade.

Uma abordagem que parte do campo das ciências sociais da religião, como a de Teixeira (2009b), classifica as diversas "faces" do catolicismo brasileiro em: catolicismo santorial, oficial, dos reafiliados e midiático. Outro insight sociológico é aquele proposto por Sanchis (2009:181), que, em diálogo com a obra de Max Weber, aborda o tema dos catolicismos utilizando a noção de "tipos ideais impuros" de "catolicidade". Sanchis nos instiga a pensar a diversidade interna do catolicismo em uma perspectiva sócio-histórica, capaz de compreender o cenário atual e o papel exercido pelas diversas catolicidades no Brasil contemporâneo.

Faz-se necessário relembrar que esta diversidade realmente existente nos modos de ser católico não é novidade no Brasil. Ela é constitutiva do fenômeno religioso em geral e do próprio catolicismo em particular. Segundo Cecília Mariz, a novidade católica está no enorme "grau de diversidade dentro de uma única igreja sob uma única liderança" (Mariz 2006:57). A novidade seria a dimensão da diversidade, "[...] a bagagem cultural própria de cada grupo de leigos desempenha um papel diversificador da experiência católica" (Mariz 2006:58). Configura-se, assim, um novo cenário no catolicismo brasileiro, marcado pela autonomia ampliada dos leigos, que se manifesta intensamente na atualidade. 
Mariz (2006:58-64) aponta quatro elementos que possibilitaram a emergência dessa autonomia ampliada dos católicos leigos: 1) as trocas com a modernidade, que podem ser observadas, por exemplo, na Teologia da Libertação, ao dar ênfase na participação democrática dos leigos e ao realizar uma crítica do clero; 2) o fim do monopólio do carisma, promovido por lideranças carismáticas leigas, sobretudo a partir das muitas aparições de Maria ao longo do século XX, provocando diversificação de carismas e conflitos entre sacerdotes e leigos dentro da instituição; 3) a ingerência de instituições não religiosas e do mercado no espaço da Igreja, como mídia, governos, empresas, empreendimentos turísticos, entre outros, que assumiram o controle de diversas manifestações religiosas, sobretudo aquelas ligadas ao catolicismo popular, de forte autonomia com relação à Igreja Católica; 4) como quarto e principal elemento, Mariz menciona as campanhas internas vividas pelo catolicismo, sendo que as mais importantes foram a romanização, o catolicismo da libertação (principalmente as CEBs, as pastorais sociais e da juventude) e o carismatismo católico (os Grupos de Oração, as Comunidades de Vida e Aliança, o fenômeno dos padres cantores). Brenda Carranza $(2006,2011)$ também menciona três ondas de recatolização, mas, para ela, a terceira onda configura-se como catolicismo midiático.

Diante de tal diversificação interna do catolicismo - seja no vínculo formal com a instituição, seja nas práticas autônomas dos fiéis católicos - e de seus modelos interpretativos, é pertinente perguntar, como faz Camurça (2013): qual tipo de catolicismo persiste, resiste ou se inventa? Se os católicos diminuem, qual grupo dentre eles tem perdido espaço? Se há uma recatolização, qual grupo ou tendência católica tem se consolidado? A resposta comum, e tomada muitas vezes como verdade indiscutível, é que diminuem os cristãos da libertação e crescem os católicos carismáticos. Concordamos em parte com essa afirmação; ela, entretanto, demanda um exame mais consistente e detalhado.

Vamos retomar a pergunta: qual grupo interno ao catolicismo tem sido favorecido e qual tem sido prejudicado na nova conjuntura? Pensamos que é possível dialogar sobre o tema a partir de um breve diagnóstico de três importantes práticas católicas: as desenvolvidas nas Novas Comunidades de Vida, nas Comunidades Eclesiais de Base e no catolicismo popular do culto aos santos. Ao acompanharmos os estudos de Mariz \& Lopes (2009) sobre a Toca de Assis, considerada aqui como uma Nova Comunidade Católica do campo carismático, evidenciamos que, com esse movimento, surge um modelo de catolicismo pulsante no cenário nacional, capaz de congregar a juventude de classe média, um segmento etário e social muito disputado no mercado religioso. Mesmo assumindo posturas rigorosas diante da modernidade, algumas delas nitidamente contrárias às formas que predominam no meio juvenil, essa nova comunidade religiosa, nascida em Campinas-SP, se destacou e alcançou ressonância entre os jovens. "Os católicos engajados nesse movimento adotam com maior frequência o discurso oficial da Igreja, frequentam mais assiduamente a missa e participam dos "grupos de oração” (Mariz \& Lopes 2009:75). A Toca de Assis é 
considerada uma Nova Comunidade por não possuir vínculos institucionais com o movimento carismático: tem estruturas próprias e autonomia perante a coordenação nacional da Renovação Carismática Católica. Porém, suas práticas são profundamente influenciadas por essa tendência.

Mariz \& Lopes, portanto, confirmam a perspectiva de crescimento do catolicismo por meio de sua vertente carismática. Além disso, pesquisas acerca do tema demonstrariam que houve um considerável crescimento no número de carismáticos no Brasil. Faz-se necessário lembrar que não existe nenhuma categoria nas pesquisas feitas pelos Censos que compreenda o carismatismo. Por conseguinte, não existem dados oficiais porque o Censo não captou esta modalidade de experiência religiosa ${ }^{8}$. O que existe são estimativas estabelecidas por alguns especialistas que informam números sem dar muitos detalhes de como chegaram a calcular tal quantidade. Por exemplo, Pedro Ribeiro de Oliveira (1978), em obra inaugural acerca dos carismáticos, apresentou estimativas desse grupo católico na década de 1970. Já em pesquisa desenvolvida nos anos 1990, Reginaldo Prandi (1998) estimava que o "Movimento de Renovação Carismática Católica" alcançava 4\% da população, aproximadamente 6 milhões de brasileiros. Mais recentemente, Edward L. Cleary (2011) informa que, nos anos 2000, havia no Brasil cerca de 33,7 milhões de católicos carismáticos, representando em torno de $22 \%$ da população católica em nosso país. Assim, se compararmos as estimativas feitas nos anos 1990 com aquelas dos anos 2000, identificaremos um crescimento significativo dos católicos de vertente carismática no país.

Seriam então os "cristãos da libertação" os responsáveis pela queda percentual do catolicismo nos últimos Censos? Ivo Lesbaupin (2009) afirmou que não. O autor considera que as CEBs, apesar de desaparecerem dos noticiários (tendo em vista que já foram, em décadas anteriores, um fenômeno midiático) e de contarem cada vez menos com apoio institucional, se encontram vivas, ativas e consolidadas. Para chegar a essa constatação, ele faz um balanço otimista da atuação das comunidades eclesiais nos últimos anos, demonstrando sua forte presença e atuação no campo católico. No entanto, também na discussão sobre o tamanho dessa vertente católica, ponderamos que nunca houve no Brasil pesquisas que pudessem apontar estatisticamente um número confiável, mesmo que aproximado, da quantidade de católicos vinculados às CEBs. Portanto, não podemos afirmar concretamente que o cristianismo da libertação mantém sua força por meio das comunidades de base. Se há incertezas quanto aos números referentes aos carismáticos, com relação aos cristãos da libertação a dúvida é ainda maior.

Continuando, ao analisarmos os grupos e estilos de catolicismo que mais crescem ou diminuem, nos deparamos com os estudos de Renata Menezes (2009) e Roberta Campos (2009). As autoras apontam que também o culto aos santos, um modelo tradicional de catolicismo muito vinculado àquele de matriz popular (mas não só, visto que há muito culto aos santos entre católicos carismáticos e da libertação), 
continua persistente. A fidelidade à devoção aos santos assenta-se no fato de que "as relações entre os santos e os fiéis são pessoais e baseadas no princípio da proteção e lealdade" (Campos 2009:141). Mesmo que recente levantamento do Instituto Datafolha (Balloussier 2017) tenha indicado que o culto aos santos no Brasil recuou de 49\% da população em 2007 para 38\% dos brasileiros em 2017, tal devoção envolve cerca de 77 milhões de pessoas, o que continua sendo um dado significativo.

Se o catolicismo carismático parece estar em plena efervescência, se o cristianismo da libertação mantém, em alguma medida, sua presença no cenário religioso, mesmo que os dados estatísticos para tal afirmação sejam escassos, e o catolicismo popular do culto aos santos resiste na cultura católica, onde decresce o catolicismo? Nossa hipótese é que, ao classificar os católicos entre praticantes e não praticantes (Rumstain \& Almeida 2009), a queda se tem dado entre os não praticantes, que possuem vínculos cada vez mais frouxos com a instituição, principalmente no caso daqueles que cresceram em famílias cujos pais já eram católicos não praticantes. Quando se pensa a Igreja Católica como doadora universal no mercado de bens de salvação, consideramos que o grupo dos não praticantes é o responsável pela adesão às outras religiões, mas também pela readesão ao próprio catolicismo, seja qual for sua vertente. Assim, provavelmente todos os três segmentos católicos mencionados acima tanto perdem quanto atraem adeptos, sendo que as Comunidades de Base do catolicismo social e politicamente crítico, bem como os segmentos do catolicismo popular tradicional, por razões e em intensidade distintas, mais perdem do que atraem seguidores. De fato, o catolicismo carismático tem sido o fator mais importante em relação ao processo de pentecostalização do cristianismo, como podemos observar na obra de Marion Aubrée $(1983,1984,1986)$ e nos recentes estudos sobre os carismáticos no Brasil (Carranza 2011; Sofiati 2012).

Todavia, para além das observações apresentadas acima, é necessário considerar que o catolicismo, ao possuir um potencial de incorporar a diversidade (Teixeira $\&$ Menezes 2009), torna as fronteiras entre seus diversos modos de ser nem fixas e nem definitivas, mas ao contrário, as mantém fluidas, frouxas, transponíveis. Dessa forma, pensar qual catolicismo tem se destacado torna-se um desafio não apenas pelas dificuldades em encontrar números seguros, mas pela própria configuração sociorreligiosa do catolicismo.

Por fim, é importante considerar a análise de Carlos Steil (2009), que formula uma crítica acerca das variadas formas de se pensar a diversidade católica no Brasil: "As tipologias com que se procurou classificar o catolicismo, especialmente a divisão entre catolicismo popular tradicional (devocional) e catolicismo clerical, sacramental, romanizado, parecem ser pouco funcionais hoje para compreender o catolicismo contemporâneo" (Steil 2009:152). O autor entende que não há fronteiras evidentes entre as diferentes formas de ser católico no Brasil e, por isso, é preciso "[...] ver o catolicismo como prática dialógica e interativa, onde se fazem presentes múltiplas vozes que competem e negociam entre si, num processo de enunciação e performance 
constante" (Steil 2009:155). Estamos de acordo com esse autor e procuramos considerar essa preocupação quando estabelecemos neste artigo nossa análise pautada na diferenciação entre Igreja Católica, a instituição, e catolicismo (ou cultura católica), a prática sociorreligiosa dos seus leigos.

\section{À guisa de conclusão: ensaios de interpretação}

Para finalizar este painel sociológico de parte da bibliografia acerca do catolicismo no Brasil contemporâneo, finalizamos com algumas considerações a partir das provocações de Carlos Rodrigues Brandão (2013), cotejando-as com alguns autores trabalhados neste texto. Brandão traz contribuições produtivas para a discussão do nosso tema. Seu incômodo inicial diz respeito ao fato de que, nos levantamentos censitários realizados pelo IBGE, a pergunta feita pelo recenseador às pessoas é: "Qual a sua religião?". O autor afirma que, para as ciências sociais da religião, o importante seria registrar a resposta à pergunta: "Como você vive sua religião?". Ele lembra que o Censo não pensa, apenas conta e soma. Cabe aos pesquisadores fazer a análise dos dados. Lembra também que os números podem enganar, visto que o campo religioso brasileiro está aberto a diferentes alternativas de práticas de fé.

Para Brandão, o catolicismo é o melhor exemplo de uma tradição religiosa com um sistema de sentido pluriaberto, multicênico e em constante transformação. Como afirma, o cenário religioso favorece a tendência à abertura e diversificação do catolicismo, com o surgimento de múltiplas variações internas. $\mathrm{O}$ catolicismo, segundo o autor, também tende a seguir a moda que desqualifica as relações interindividualizadas - tipo de fé face a face - presentes, por exemplo, no núcleo familiar. Brandão vê duas razões para esse cenário: 1) ênfase nas relações por meio de comunidades identitárias e de mútuo reconhecimento (como as novas comunidades carismáticas e grupos mais tradicionais como os Arautos do Evangelho e a Tradição, Família e Propriedade - TFP); 2) tendência a uma religião midiática com múltiplos clientes, aquela que se acompanha pelo rádio, pela televisão e pelos meios de comunicação presentes na Internet (encontrada no tipo de catolicismo midiático).

Mas o que garantiria certa unidade dos católicos em tal cenário? Brandão identifica três fatores concomitantes: a) o catolicismo continua sendo uma "religião de todos", isto é, permanece ainda muito presente na cultura dos brasileiros; b) o catolicismo não exige confissão pública da fé, basta o vínculo social dos sacramentos (batismo, crisma, casamento, etc.) para alguém ser considerado católico; c) o catolicismo tende a abrir-se, ou seja, seus adeptos, em geral, estão mais aptos a aceitar outras religiões e, inclusive, a frequentar outras igrejas com menos constrangimentos no caso da manutenção do vínculo mesmo que frouxo com a Igreja Católica. Todos esses elementos puderam ser identificados na análise apresentada neste painel bibliográfico, considerando, por exemplo, o fato de o catolicismo ser uma religião propensa ao sincretismo (Campos 2009). 
Em um contexto de maior concorrência no campo religioso, da emergência do individualismo, do empoderamento relativo dos leigos católicos, do livre acesso à Internet e de massificação nas comunicações, aliados a mudanças no campo da cultura global, o catolicismo tende a se tornar mais diversificado e menos controlável em termos de trocas simbólicas com outras religiões e até mesmo com a cultura midiática (Martins 2009:128). Entretanto, se isso o torna potencialmente a religião de todos, também o faz uma igreja de poucos (Brandão 2013). A Igreja Católica é a instituição que melhor representa a tradição no moderno mercado das religiões. No caso brasileiro, o catolicismo é também, como lembra Brandão (2013), a religião "do casal”, com foco na família nuclear, diante de um cenário que estimula o individualismo e a religião do self. A Igreja Católica é a igreja da família brasileira, segundo o slogan da maior TV católica do Brasil, a Rede Vida (Placeres 2015). Mas é uma religião que parte da família para a comunidade, num contexto no qual o pentecostalismo dissolve os laços de parentesco da família tradicional e fortalece cada vez mais o modelo de família unida por vínculos de afinidade eletiva. Em texto conhecido, Pierucci (2006a) já identificava o pentecostalismo como um solvente, como uma religião que dissolve os laços de parentesco, os vínculos com a cultura tradicional e que "libera" os indivíduos de seus amarramentos às comunidades tradicionais e étnicas. Consequentemente, a família tem se tornado uma instituição cada vez menos eficaz em termos de transmissão religiosa, se comparada com as décadas anteriores, como apontaram Ronaldo Almeida e Rogério Barbosa (2013:316). Esses autores observaram que "na média, sempre foi e ainda é mais provável que um indivíduo nasça católico no Brasil". Porém, informam que "a probabilidade de permanecer católico é decrescente nas primeiras fases do ciclo de vida, ao passo que as probabilidades de todas as demais religiões são crescentes" (Almeida \& Barbosa 2013:316).

Almeida \& Barbosa afirmam que, do ponto de vista demográfico, todas as religiões e os sem religião se comportam de modo diferente dos católicos, comprovando que há hoje uma ineficiência na transmissão dos mais velhos para os mais novos. Em outro texto, Almeida, em parceria com Rumstain, chega a afirmar que o catolicismo é entendido como uma segunda religião entre os indivíduos criados em famílias católicas não praticantes (Rumstain \& Almeida 2009:38). Lembremos que, já nos anos 1990, Sanchis (1994) sugeria entender o catolicismo como uma segunda religião. Também autores ligados diretamente ao campo católico identificaram a perda da eficácia do discurso católico oficial. Benedetti (2009) acredita que isso ocorre pelo fato de a instituição não ter a realidade histórica concreta das pessoas como horizonte de ação, assumindo em vez disso a si mesma e à sua reprodução como prioridades. Benedetti afirma que hoje ocorre um diálogo de surdos entre a instituição e seus fiéis. A Igreja Católica vê os indivíduos como perdidos, desgarrados, mas eles não se veem assim. Os indivíduos, em contrapartida, veem uma instituição que não tem nada a lhes dizer, a não ser que estão fora do caminho, como pouco importante. 
Para nós, ainda que pouco estudada, a longa e enraizada tradição do clericalismo centralizador, fortalecida no contexto brasileiro pelo processo de romanização, é o fator interno mais problemático para a Igreja Católica responder à atual conjuntura. A centralidade da iniciativa e da legitimação dependendo quase exclusivamente da figura do padre celibatário torna-se totalmente disfuncional numa cultura global marcada pela iniciativa dos indivíduos, pelo culto à inovação e à mudança constante, portanto pela crise de toda autoridade simbólica (fora da ciência e do mercado) e pelo gosto pela experimentação e a bricolagem. Além disso, o clericalismo não responde à exigência de igualdade de gênero em todos os níveis e só faz aumentar a pouca mobilidade e até ausência da estrutura católica nas periferias e áreas de ocupação recente. Quando, então, há uma queda pronunciada no número de sacerdotes, como atualmente, a crise da Igreja clerical pode assumir proporções dramáticas, como a vivida hoje nos países centrais europeus. No Brasil, as instâncias de pensamento crítico que apoiavam as iniciativas e os organismos decisórios dos leigos, como aquelas inspiradas na Teologia da Libertação, foram em boa parte descontinuadas, desmontadas ou mesmo perseguidas. Com a "volta à grande disciplina" (Libânio 1984), perdeu-se um contingente considerável de "leigos engajados" e de agentes pastorais qualificados, que já não se identificam com o modelo clerical. Isso contribui para explicar o baixo nível de mobilização e de reação de lideranças católicas populares diante da expansão das igrejas pentecostais, justamente nas periferias, classes médias e áreas de fronteira.

Nesse contexto, Brandão (2013:102) constata que "[...] em vários cenários há mais 'cristãos católicos na diáspora' do que 'católicos cristãos paroquiais”. De nossa parte, identificamos uma cultura católica que persiste nas mais variadas formas de práticas da fé, tornando questionável se a intensidade da perda de fiéis continuará de forma linear nas próximas décadas, como acreditam alguns (Vale 2017). Mas isso também não podemos afirmar. O que é possível defender a partir deste parcial painel bibliográfico é a tese da manutenção da importância dos catolicismos no cenário nacional. Compreendemos que, mesmo com a diminuição da importância da instituição, se manteve a influência da cultura católica, visto que a tese da desinstitucionalização e do enfraquecimento dos vínculos cabe bem no caso da Igreja Católica, que é um exemplo concreto desse processo. Mesmo com a estrutura centralizadora da instituição, mantida a lógica da diversificação e o provável aumento da diversidade interna católica, a Igreja Católica tende a se tornar uma religião de consumidores de bens de salvação relativamente isolados e com vínculos fluidos entre si.

Talvez essa seja a resposta da Igreja Católica (ou a consequência do cenário de autonomia ampliada dos fiéis), que veria no esgarçamento do vínculo com seus fiéis o preço a ser pago para reforçar a organicidade interna da instituição. Se tal diagnóstico tiver alguma comprovação, estaríamos diante da análise de Pierucci que sentenciava o seguinte: "A igreja católica exige muitíssimo de uns poucos (monges e freiras, bispos e padres) e pouco, bem pouco dos muitos" (2009:15). Seria essa, mais uma vez, sua estratégia fundamental ante o atual cenário religioso no Brasil? 


\section{Referências Bibliográficas}

AUBRÉE, Marion. (1983), "Du pentecôtisme en Amérique Latine". Critique Socialiste, no 47: 42-51. . (1984), "Les nouvelles tribus de la chrétienté". Raison Présente, nº 72 : 71- 87.

. (1986), "A penetração do protestantismo evangelizador na América Latina". Comunicações do ISER, $\mathrm{n}^{\circ} 23: 35-44$.

AUBRÉE, Marion \& LAPLANTINE, François. (1990), La table, le livre e les esprits: naissance, évolution et actualité du mouve-social spirite, entre France et Brésil. Paris: Éd. J.C. Lattès.

ALMEIDA, Ronaldo \& BARBOSA, Rogério. (2013), "Transmissão religiosa nos domicílios brasileiros". In: F. Teixeira \& R. Menezes (orgs.). Religiões em movimento: o CENSO de 2010. Petrópolis-RJ: Vozes. AZZI, Riolando. (2008), A Igreja Católica na formação da sociedade brasileira. Aparecida-SP: Santuário. BASTIDE, Roger. (2001), O candomblé da Bahia. São Paulo: Companhia das Letras.

BENEDETTI, Luiz R. (2009), "Novos rumos do catolicismo". In: B. Carranza et al. (orgs.). Novas comunidades católicas: em busca do espaço pós-moderno. São Paulo: Idéias \& Letras.

BITTENCOURT FILHO, José. (2003), Matriz religiosa brasileira. Petrópolis-RJ: Vozes.

BOFF, Leonardo. (1994), Igreja: carisma e poder. São Paulo: Ática.

BRANDÃO, Carlos Rodrigues. (2004), "Fronteira da fé: alguns sistemas de sentido, crenças e religiões no Brasil de hoje". Estudos Avançados, vol. 18, nº 52: 261-288.

. (2013), "Catolicismo. Catolicismos?". In: F. Teixeira \& R. Menezes (orgs.) Religiões em movimento: o CENSO de 2010. Petrópolis-RJ: Vozes.

CAMPOS, Roberta B. (2009), "Interpretações do catolicismo: do sincretismo e antissincretismo na/da cultura brasileira”. In: F. Teixeira \& R. Menezes (orgs.). Catolicismo plural: dinâmicas contemporâneas. Petrópolis-RJ: Vozes.

CAMPOS, Roberta B. C. \& GUSMÃO, Eduardo H. A. (2013), "Reflexões metodológicas em torno da conversão na IURD: colocando em perspectiva alguns consensos". Estudos de Sociologia, vol. 18, nº 34: 57-74.

CAMURÇA, Marcelo A. (2006), "A realidade das religiões no Brasil no CENSO do IBGE-2000". In: F. Teixeira \& R. Menezes (orgs.). As religiões no Brasil: continuidades e rupturas. Petrópolis-RJ: Vozes.

. (2011), "Crise ou recomposição do catolicismo na esfera pública: uma análise comparada entre uma literatura da França e do Brasil”. BOLETIM CEDES, out./dez.: 1-12.

. (2013), "O Brasil religioso que emerge do CENSO de 2010: consolidações, tendências e perplexidades”. In: F. Teixeira \& R. Menezes (orgs.). Religiões em movimento: o CENSO de 2010. Petrópolis-RJ: Vozes.

CARRANZA, Brenda. (2006), "Catolicismo midiático". In: F. Teixeira \& R. Menezes (orgs.). As religiões no Brasil: continuidades e rupturas. Petrópolis-RJ: Vozes.

. (2011), Catolicismo midiático. Aparecida-SP: Idéias \& Letras.

. (2015), "Cristianismo pentecostal: nova face da Igreja Católica". In: A. S. Moreira \& P. L. Trombetta (orgs.). Pentecostalismo globalizado. Goiânia: Editora da PUC.

CLEARY, Edward L. (2011), The rise of Charismatic Chatholicism in Latin America. EUA: University Press of Florida.

COSTA, Moab C. (2011), Mudança no ethos do pentecostalismo clássico para o neopentecostalismo. Estudo de caso: a AD em Imperatriz-MA. Goiânia: Dissertação de Mestrado em Ciências da Religião, PUC Goiás.

FERNANDES, Sílvia R. A. (2013), "Os números de católicos no Brasil - Mobilidades, experimentações e propostas não redutivistas na análise do CENSO”. In: F. Teixeira \& R. Menezes (orgs.). Religiões em movimento: o CENSO de 2010. Petrópolis-RJ: Vozes.

GIDDENS, Anthony. (1991), As consequências da modernidade. São Paulo: Editora UNESP.

GRACINO JUNIOR, Paulo. (2012), “'A visão aérea e a do nadador': reflexões sobre católicos e pentecostais no censo de 2010". Revista Horizonte, vol. 10, no 28: 1154-1183.

HERVIEU-LÉGER, Danièle. (1999), Le pelegrin et le converti: la religion en mouviment. Paris: Flammarion. LESBAUPIN, Ivo. (2009), "Comunidades de base no Brasil de hoje". In: F. Teixeira \& R. Menezes (orgs.). Catolicismo plural: dinâmicas contemporâneas. Petrópolis-RJ: Vozes. 
LIBÂNIO, João B. (1984), A volta à grande disciplina. São Paulo: Loyola.

. (1999), Cenários da Igreja. São Paulo: Loyola.

(2012), Cenários da Igreja num mundo plural e fragmentado. São Paulo: Loyola, $5^{\text {a }}$ ed.

LÖWY, Michel. (2000), A guerra dos deuses: religião e política na América Latina. Petrópolis-RJ: Vozes.

MACHADO, Maria das D. C. (2014), "Moral sexual e ação política dos pentecostais". In: A. P. Oro; M.

Tadvald (Orgs.). Circuitos religiosos: pluralidade e interculturalidade. Porto Alegre: CirKula.

MARIZ, Cecília L. (2006), "Catolicismo no Brasil contemporâneo: reavivamento e diversidade". In: F. Teixeira \& R. Menezes (orgs.). As religiões no Brasil: continuidades e rupturas. Petrópolis-RJ: Vozes.

MARIZ, Cecília L. \& LOPES, Paulo V. L. (2009), "O reavivamento católico no Brasil e o caso da Toca de Assis”. In: F. Teixeira \& R. Menezes (orgs.). Catolicismo plural: dinâmicas contemporâneas. Petrópolis-RJ: Vozes.

MARIZ, Cecília L. \& THEIJE, Marjo. (2008), "Localizing and globalizing processes in Brazilian Catholicism. Comparing Inculturation in Liberationist and Charismatic Catholic Cultures". Latin American Research Review, vol. 43, n1:33-54.

MARTINS, Andrea D. (2009), "Catolicismo contemporâneo: tratando da diversidade a partir da experiência religiosa dos fiéis”. In: E. de C. Gomes (org.). Dinâmicas contemporâneas do fenômeno religioso na sociedade brasileira. São Paulo: Idéias \& Letras.

MENEZES, Renata. (2009), "Santo Antônio no Rio de Janeiro: dimensões da santidade e da devoção". In: F. Teixeira \& R. Menezes (orgs.). Catolicismo plural: dinâmicas contemporâneas. Petrópolis-RJ: Vozes.

MOREIRA, Alberto da S. (2008), "O futuro da religião no mundo globalizado: painel de um debate". In: A. da S. Moreira \& I. D. de Oliveira (orgs.). O futuro da religião na sociedade global. São Paulo: Paulinas/PUC Goiás.

. (2018), "From Religious Diversity to Political Competition: The Differentiation Process of Pentecostalism in Brazil". Religions, vol. 9, nº 1: 1-11. Disponível em: http://www.mdpi.com/20771444/9/1/14. Acesso em: 10/07/2018.

NEGRÃO, Lísias N. (2009), Novas tramas do sagrado. Trajetórias e multiplicidades. São Paulo: EDUSP.

OLIVEIRA, Pedro A. R. de (Org.). (1978), Renovação carismática católica: uma análise sociológica e interpretações teológicas. Petrópolis-RJ: Vozes.

PEW RESEARCH CENTER. (2017), The Changing Global Religious Landscape. Disponível em: http:// www.pewforum.org/2017/04/05/the-changing-global-religious-landscape/. Acesso em: 14/11/2017.

PIERUCCI, Antônio Flávio. (2006a), "Religião como solvente: uma aula". Novos Estudos CEBRAP, no $75: 111-127$.

. (2006b), "Cadê nossa diversidade religiosa? - Comentários ao texto de Marcelo Camurça". In: F. Teixeira \& R. Menezes (orgs.). As religiões no Brasil: continuidades e rupturas. Petrópolis-RJ: Vozes. . (2009), "É fácil ser católico". In: F. Teixeira \& R. Menezes (orgs.). Catolicismo plural: dinâmicas contemporâneas. Petrópolis-RJ: Vozes.

. (2013), "O crescimento da liberdade religiosa e o declínio da religião tradicional: a propósito do CENSO de 2010”. In: F. Teixeira \& R. Menezes (orgs.). Religiões em movimento: o CENSO de 2010. Petrópolis-RJ: Vozes.

PLACERES, Giulliano. (2015), O empreendedorismo econômico televisivo da Rede Vida de Televisão. São Carlos-SP: Dissertação de Mestrado em Sociologia, UFSCar.

PRANDI, Reginaldo. (1998), Um sopro do espírito: a renovação conservadora do catolicismo carismático. São Paulo: EDUSP.

KONINGS, Johan \& MORI, Geraldo L. (2012), "A evolução da Igreja Católica no Brasil à luz de pesquisas recentes". Horizonte, vol. 10, no 28: 1208-1229.

REESINK, Mísia L. (2013), "Por uma perspectiva concêntrica do catolicismo brasileiro". Revista ANTHROPOLÓGICAS, ano 17, vol. 24, nº 2: 161-187.

RIBEIRO, Jorge C. (2009), Religiosidade Jovem: pesquisa entre universitários. São Paulo: Olho D'água/ FAPESP/Loyola.

RODRIGUES, Donizete. (2013), O que é religião? A visão das ciências sociais. Aparecida-SP: Santuário. 
RUMSTAIN, Ariana \& ALMEIDA, Ronaldo. (2009), "Os católicos no trânsito religioso”. In: F. Teixeira \& R. Menezes (orgs.). Catolicismo plural: dinâmicas contemporâneas. Petrópolis-RJ: Vozes.

SANCHIS, Pierre. (1994), "O repto pentecostal à cultura católico-brasileira". In: A. Antoniazzi (org.). Nem anjos, nem demônios: interpretações sociológicas do pentecostalismo. Petrópolis-RJ: Vozes. . (2009), "Perspectivas antropológicas sobre o catolicismo". In: F. Teixeira \& R. Menezes (orgs.). Catolicismo plural: dinâmicas contemporâneas. Petrópolis-RJ: Vozes.

. (2013), "Prefácio". In: F. Teixeira \& R. Menezes (orgs.). Religiões em movimento: o CENSO de 2010. Petrópolis-RJ: Vozes.

SILVA, Wellington Teodoro da. (2018), Catolicismo e Golpe de 1964. Belo Horizonte: Editora PUC Minas.

SILVEIRA, João P. P. (2012), "Tradução, mercado religioso e novidade religiosa: considerações sobre a Seicho-No-Ie no Brasil". In: Anais do 25ํㅡㄹ Congresso Internacional da SOTER. Belo Horizonte: SOTER/PUC-MG.

SOFIATI, Flávio M. (2012), Religião e juventude: os novos carismáticos. São Paulo: Ideias \& Letras/ FAPESP.

. (2015), "Perspectivas da laicidade no Brasil contemporâneo". Revista Contemporânea, vol. 5, n $2: 327-350$.

SOFIATI, Flávio M. \& MORAIS, Péricles. (2016), "Acorda Canção Nova!: conservadores católicos e eleições presidenciais em 2010”. In: S. Brandão \& N. D. de A. Cabral (orgs.). Coletânea História das Religiões no Brasil, volume 7. Recife: Editora Universitária da UFPE/Associação de Imprensa de Pernambuco.

. (2017), "O Papa Francisco, o comunismo e o crucifixo". In: E. Pace et al. (orgs.). Fundamentalismos religiosos, violência e sociedade. São Paulo: Fonte Editorial/FAPEG.

STEIL, Carlos A. (2009), "A cultura já não é mais a mesma”. In: F. Teixeira \& R. Menezes (orgs.). Catolicismo plural: dinâmicas contemporâneas. Petrópolis-RJ: Vozes.

TEIXEIRA, Faustino. (2009a), "A conjuntura internacional católica: a relação com as religiões". In: F. Teixeira \& R. Menezes (orgs.). Catolicismo plural: dinâmicas contemporâneas. Petrópolis-RJ: Vozes. . (2009b), "Faces do catolicismo brasileiro contemporâneo". In: F. Teixeira \& R. Menezes (orgs.). Catolicismo plural: dinâmicas contemporâneas. Petrópolis-RJ: Vozes.

. (2013), "O CENSO de 2010 e as religiões no Brasil: esboço de apresentação". In: F. Teixeira \& R. Menezes (orgs.). Religiões em movimento: o CENSO de 2010. Petrópolis-RJ: Vozes.

TEIXEIRA, Faustino \& MENEZES, Renata (orgs.). (2006), As religiões no Brasil: continuidades e rupturas. Petrópolis-RJ: Vozes.

. (2009), Catolicismo plural: dinâmicas contemporâneas. Petrópolis-RJ: Vozes.

. (2013), Religiões em movimento: o CENSO de 2010. Petrópolis-RJ: Vozes.

\section{Jornais e revistas consultados}

BAILEY, Sarah P. (2017), "How the prosperity gospel is sparking a major change in predominantly Catholic Brazil". The Washington Post, 31 Oct. 2017.

BALLOUSSIER, Anna Virginia. (2017), "Aparecida é padroeira de um país cada vez menos devoto a santos". Folha de S. Paulo, 12 out. 2017. Disponível em: http://www1.folha.uol.com.br/poder/2017/10/1926459-aparecida-e-padroeira-de-um-pais-cada-vez-menos-devoto-a-santos.shtml. Acesso em: 12/10/2017.

ISTO É. "O Brasil é uma potência religiosa global". Isto É, 13 mar. 2012. Disponível em: http://istoe. com.br/194952_O+BRASIL+E+UMA+POTENCIA+RELIGIOSA+GLOBAL+/. Acesso em: 29/06/2017.

PINTO, Ana Estela de Sousa. (2016), "Nova geração de evangélicos ocupa metade dos bancos das igrejas". Folha de S. Paulo, 25 dez. 2016. Disponível em: https://www1.folha.uol.com.br/poder/2016/12/1844387-nova-geracao-de-evangelicos-ocupa-metade-dos-bancos-das-igrejas.shtml. 


\section{Sites consultados}

DATAFOLHA. (2016), Perfil e opinião dos evangélicos no Brasil. Amostra PO813906, 08/12/2016. Disponível em: http://datafolha.folha.uol.com.br/opiniaopublica/2016/12/1845231-44-dos-evangelicossao-ex-catolicos.shtml. Acesso em: 20/06/2017.

VALE, Inácio J. do. (2017), "Diminuição progressiva de católicos no Brasil: até que ponto?". Aleteia, 7 ago. 2017. Disponível em: https://pt.aleteia.org/2017/08/07/diminuicao-progressiva-de-catolicosno-brasil-ate-que-ponto/. Acesso em: 16/10/2017.

\section{Notas}

1 Texto produzido com apoio do CNPq por meio da bolsa de Pós-Doutorado Júnior no país. Pesquisa realizada no Programa de Pós-Graduação em Ciências da Religião da PUC-Goiás.

2 O levantamento foi feito tendo como referência as edições de 2010 a 2017 das seguintes revistas da área de ciência humanas no Brasil: Sociologias, Tempo Social, Revista Brasileira de Ciências Sociais, Revista Brasileira de Sociologia, Sociedade e Cultura, Sociedade Eु Estado, Contemporânea, Psicologia: ciência e profissão, Estudos de Sociologia, Religião $\mathfrak{E}$ Sociedade, Horizonte, Estudos de Religião, Rever, Ciências Sociais e Religião, Debates do NER, Numen, Caminhos, Boletim CEDES e Revista Brasileira de História das Religiões, além de dossiês sobre religião em outras revistas brasileiras. Pesquisamos também na SciELO as palavras-chave "Igreja Católica", "catolicismo" e "católica". Foram encontrados em torno de 55 artigos que tratam do tema no Brasil contemporâneo, sendo que a maioria analisa aspectos do catolicismo, principalmente de sua vertente carismática.

3 No caso de Aparecida, tem havido diminuição no número de peregrinos na Festa da Padroeira em 12 de outubro. Todavia, mantém-se a grande massa de peregrinação durante todo o ano, potencializada pelo roteiro religioso que passa pela Comunidade Canção Nova, do Movimento Carismático, e o Mosteiro de Frei Galvão, único santo nascido no Brasil.

4 Cf. a pesquisa de campo efetuada por Moab C. Costa (2011), para a sua dissertação de mestrado, nas Assembleias de Deus em Imperatriz, Maranhão.

5 Folha de S. Paulo, 25/12/2016. Quatro em dez jovens pentecostais (até 25 anos) admitem não seguir as restrições alcóolicas de suas igrejas: http://www1.folha.uol.com.br/poder/2016/12/1844387-novageracao-de-evangelicos-ocupa-metade-dosbancos-das-igrejas.shtml.

${ }^{6}$ Nesse sentido, a movimentação dos fiéis no campo (sobretudo no estudo etnográfico mencionado pela autora) parece vir apenas da atração ou da decisão subjetiva das pessoas; não aparecem condicionantes estruturais, estratégias de evangelização, mecanismos de convencimento ou políticas de expansão institucional. Além disso, tais estratégias e condicionantes não partem apenas do centro teológico, podem vir igualmente dos diversos grupos e movimentos católicos. Também eles parecem ter um centro teológico (próprio), o que complexifica a visualização esquemática. Mesmo que o centro não deva ser pensado como um eixo vertical ou horizontal, o modelo refere-se estruturalmente a um centro e a uma periferia (núcleo e bordas, como numa célula).

7 Como um possível aprimoramento da metáfora visual apresentada por Reesink (2013:180) em seu artigo, sugerimos que o modelo concêntrico do catolicismo brasileiro seja pensado não em termos bidimensionais, como uma superfície em torno de um centro, conforme parece sugerir o diagrama, mas que se agregue também massa, profundidade e densidade aos "pontos", ou seja, que o modelo seja pensado tridimensionalmente. As posições dos agentes não revelam apenas uma localização pontual numa superfície, mas também uma massa, um volume para baixo, com graus variáveis de densidade, que tornam a "mancha" mais ou menos compacta, mais ou menos permeável. Seguindo a metáfora de uma modernidade líquida proposta por Bauman, a realidade física que mais se aproxima dessa concepção parece ser a de um recipiente com líquidos de diversas densidades, propriedades e cores. Líquidos 
que, sem se misturar, se atraem e se repelem, combinam ou delineiam fronteiras mais ou menos claras, formando manchas, aglomerados próprios conforme o movimento e a carga elétrica a que todos estão permanentemente submetidos. Poder-se-ia imaginar óleos de diferentes densidades e propriedades que flutuam e formam manchas, volumes e configurações próprias num recipiente de água, sendo o recipiente e as manchas pervadidas o tempo todo por um campo energético.

8 Brenda Carranza (2015), a partir de pesquisa do Pew Research Center, informa que há cerca de 305 milhões de carismáticos nas Américas.

Submetido em: $15 / 11 / 2017$

Aceito em: 26/07/2018

Flávio Munhoz Sofiati (sofiati@gmail.com)

Professor Associado da Faculdade de Ciências Sociais, do Programa de PósGraduação em Sociologia e do Programa de Pós-Graduação em Antropologia Social da Universidade Federal de Goiás (UFG), Goiânia, GO, Brasil; Doutor em Sociologia pela Universidade de São Paulo (USP), São Paulo, SP, Brasil.

Alberto da Silva Moreira (alberto-moreira@uol.com.br) Professor Adjunto do Programa de Pós-Graduação Stricto Sensu em Ciências da Religião da Pontifícia Universidade Católica de Goiás (PUC Goiás), Goiânia, GO, Brasil; Coordenador do Núcleo de Estudos Avançados em Religião e Globalização e do Centro de Estudos Brasil-Oriente Médio, PUC Goiás; Pesquisador do CNPq, Brasil. 


\section{Resumo:}

\section{Catolicismo brasileiro: um painel da literatura contemporânea}

O artigo apresenta um painel da literatura contemporânea sobre o catolicismo brasileiro. Procura-se desenvolver uma análise sob perspectiva sociológica em diálogo com outros autores das ciências humanas, principalmente da sociologia, antropologia e da teologia que tratam do fenômeno religioso no país. Não se trata de uma revisão bibliográfica no sentido estrito, e sim da construção de um argumento a partir da apreciação geral e da discussão com uma bibliografia recente e relevante sobre o tema. Constata-se a necessidade de pensar o catolicismo de forma abrangente, em contraste com estudos recentes que enfatizam aspectos particulares ou diferentes agrupamentos da Igreja Católica brasileira. Diante disso, procura-se recuperar o sentido da ação católica e de sua presença institucional na sociedade brasileira por meio da sistematização de alguns estudos recentes sobre o tema. O intuito é entender - a partir da distinção entre Igreja Católica e catolicismo - as confluências dos modos de ser católico num cenário de diversificação do cristianismo e do próprio catolicismo.

Palavras-chave: Religião, Igreja Católica, Catolicismo, Brasil, Diversificação

\section{Abstract:}

\section{Brazilian Catholicism: a review of the current literature}

The article presents a panel of contemporary literature on Brazilian Catholicism. It seeks to develop a perspective of sociological analysis in dialogue with other authors in the human sciences, mainly sociology, anthropology and theology, that deal with the religious phenomenon in the country. It is not a bibliographical revision in the strict sense, but rather the construction of an argument based on a general appreciation and discussion with recent and relevant bibliography. There is a need to think about Brazilian Catholicism in a comprehensive way, in contrast to recent studies that emphasize particular aspects or different groupings of the Brazilian Catholic Church. The article seeks to recover the meaning of Catholic action and its institutional presence in Brazilian society through the systematization of some recent studies on the subject. The aim is to understand - departing from the distinction between Catholic Church and Catholicism - the confluences of Catholic ways of being in a scenario of diversification of Christianity and Catholicism itself.

Keywords: Religion, Catholic church, Catholicism, Brazil, Diversification 